\title{
MENGGAGAS PELESTARIAN PERMUKIMAN TRADISIONAL DUSUN SADE SEBAGAI LANSEKAP BUDAYA YANG MAMPU MENGANTISIPASI KEBUTUHAN PENGHUNINYA
}

\author{
Ph. Agus Sukandar* \\ Jurusan Arsitektur, Fakultas Teknik, Universitas Merdeka Malang, \\ Jl. Puncak Jaya 25 Malang \\ phi_agus@yahoo.com
}

\begin{abstract}
ABSTRAK
Perkampungan adat di dusun Sade merupakan salah satu lansekap budaya Sasak yang sudah ditetapkan pemerintah setempat sebagai salah satu kawasan wisata di Lombok yang harus dikonservasi namun eksistensi tradisionalitasnya terancam hilang karena penduduknya merasa lingkungan permukiman ini tidak sesuai lagi dengan perkembangan kebutuhannya. Sebagai permukiman yang masih hidup, tentusaja tidak mungkin memaksakan kebijakan-kebijakan pelestarian yang sekedar melindungi artefaknya. Pengelolaan berdasar konsep pelestarian lansekap budaya merupakan upaya perlindungan yang sekaligus diharapkan bisa menjadi alat dalam mengolah transformasi dan revitalisasi suatu kawasan. Pendekatan ini diharapkan juga mampu memberikan kualitas kehidupan masyarakat yang lebih baik berdasarkan kekuatan aset-aset budaya yang ada. Proses menemukenali karakter keragaan fisik visual tatanan lansekapnya berikut preferensi masyarakat terhadap lingkungannya yang diantaranya melalui inventarisasi bentuk perubahan fisik yang terjadi, merupakan langkah awal dari seluruh kegiatan yang diperlukan.
\end{abstract}

Keywords - Tradisional, Pariwisata, Lansekap budaya,

\section{PENDAHULUAN}

Sade adalah sebuah perkampungan adat yang terletak di Desa Rambitan Kecamatan Pujut Kabupaten Lombok Tengah. Oleh pemerintah setempat kawasan ini telah lama ditetapkan sebagai salah satu tujuan wisata budaya di Lombok melalui Perda No 9 tahun 1989. Dengan Perda ini sekaligus mewajibkan Sade untuk mengkonservasi tata lingkungan termasuk seluruh bangunan tradisional yang ada di dalamnya.

Namun permukiman yang terlihat eksotis dan atraktif dari luar ini sebenarnya menyimpan permasalahan dilematis di dalamnya. Dari satu sisi kegiatan pariwisata telah mampu meningkatkan taraf hidup penduduknya. Tapi seiring dengan peningkatan perekonomian itu juga mendorong para warga Sade untuk melakukan perubahan pola hidup mereka termasuk dalam hal tempat tinggal atau rumah. (Bali Post, Juli 2008).

Bagi mereka, saat ini tatanan ruang tradisionalnya sudah tidak mampu mengakomodir kegiatan yang telah berkembang. namun sekarang tinggal bagaimana kelestarian desa Sade tetap terjaga dalam memenuhi keinginan warga untuk berkembang dan berubah.

Untuk mencapai tuntutan ini pertama yang harus ditemu kenali adalah karakter keragaan fisik visual 
tatanan lansekapnya, juga bagaimana bentuk-bentuk perubahannya sebagai salah satu upaya memahami preferensi masyarakatnya. Dengan kedua gambaran ini diharapkan bisa dirumuskan arah dan bentuk pengembangan permukiman tradisional Sade nantinya.

\section{PROFIL LANSEKAP BUDAYA SADE}

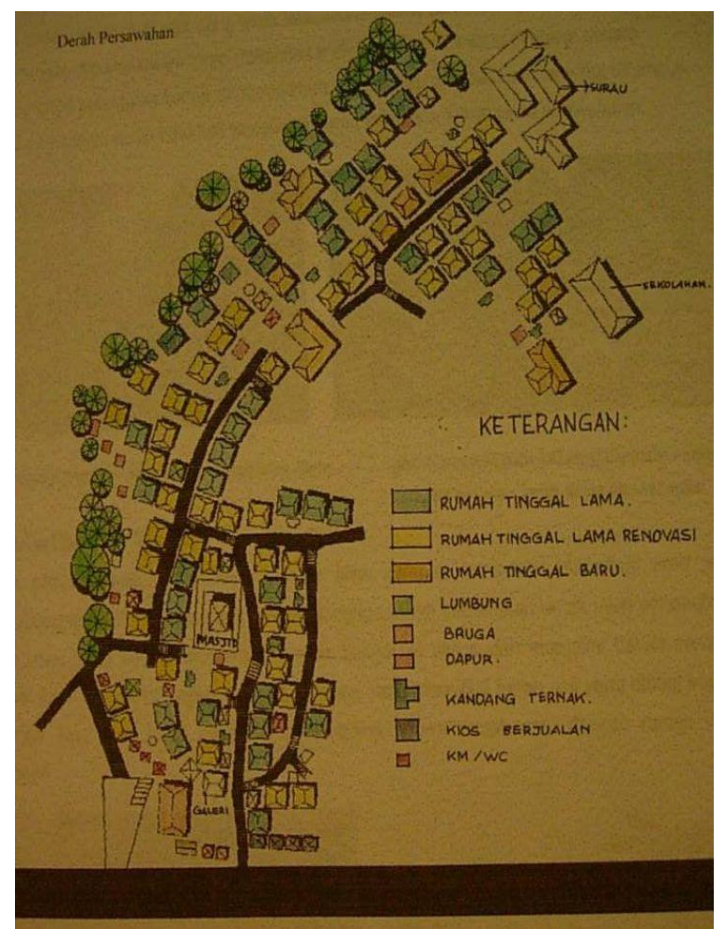

Gambar 1. Sketsa Siteplan Dusun Sade tahun 2003 (Sumber: KKN Kolektif Lombok 2003, Ars Unmer Malang).
Bentang lansekap Sade terbentuk oleh budaya agraris lingkungan perladangan tradisional. Berada di tepi jalan menuju Pantai Kuta, keberadaan perkampungan ini akan langsung menarik perhatian berkat lansekap visualnya yang kontras dengan permukiman lain. Dari jalan, kampung berada di ketinggian bukit dengan rumah-rumah penduduk bergerombol di atas hamparan perladangan terbuka tempat penggembalaan ternak di musim kemarau. Hamparan permukiman warga berderet-deret linear dengan bentuk massa yang didominasi atap berpenutup daun alang-alang. Dari dari sela-selanya bercuatan garis-garis vertikal tiang bambu yang digunakan untuk memasang antena televisi. Komposisi antara yang horisontal dengan yang vertikal ini menghasilkan sebuah vista natural yang cukup meriah, eksotis dan unik.

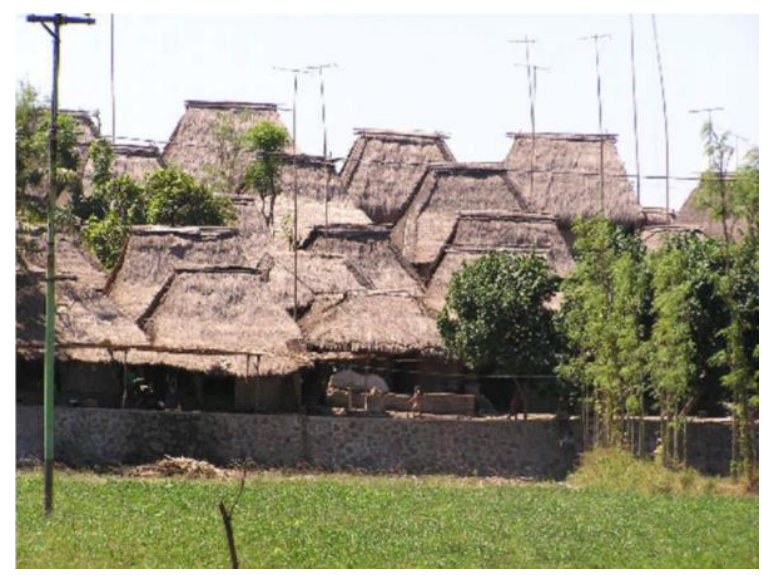

Gambar 2. Gugus Permukiman Sade dilihat dari area perladangan di luar dusun. (sumber: Setiadi Darmawan) 
Di tengah hamparan bangunan hampir seragam tersebut sebuah atap susun tiga tampak menyembul lebih tinggi di banding atap-atap yang lain. Di samping fungsi utamanya sebagai tempat ibadah warga, masjid yang juga beratap ilalang ini merupakan warisan pusaka yang masih terjaga keasliannya.

Dari dalam, permukiman yang terkesan atraktif dan berwibawa ini, lebih mengesankan pedesaan miskin yang terbelakang infrastrukturnya. Kebanyakan rumah penduduk dibangun dengan teknik dan teknologi sekedarnya. Memang ada beberapa rumah yang sudah lebih modern, tetapi jumlahnya masih lebih kecil. Bahkan karena mengambil bentuk seperti rumahrumah yang umum dikenal, bangunan ini justru terkesan menurunkan kualitas visual Sade yang khas.

Secara teoritik, sebuah kawasan bisa dikategorikan sebagai sebuah lansekap budaya apabila paling tidak memenuhi satu dari 5 (lima) kriteria, antara lain:

a. Etnografis, yang merupakan produk khas suatu sistem ekonomi dan sosial suatu kelompok/suku masyarakat (etnik).

b. Associative, suatu bentuk lansekap yang berasosiasi atau dapat dihubungkan dengan suatu peristiwa, personal, masyarakat, legenda, estetika dan sebagainya

c. Adjoining, adalah bentukan lansekap yang merupakan bagian dari suatu unit tertentu, bagian monumen, atau bagian struktur bangunan tertentu.
Secara etnografis dan associative, Sade merupakan kompleks permukiman tradisional suku Sasak. Meskipun tidak didukung bukti sejarah tertulis, beberapa orang menyatakan bahwa Sade merupakan permukiman tua yang menjadi salah satu tempat asalusul orang Sasak. Aksentuasi kultur kompleks ini adalah kultur Lombok Tengah yang mempunyai ciri sebagai pusat budaya asli Sasak yang masih melestarikan upacara-upacara tradisionalnya. Hal ini diketengahkan dalam bentuk tari-tarian adat, cara berpakaian, dan alat-alat rumah tangga serta artefak lainnya. (Penelitian ITS, 1984).

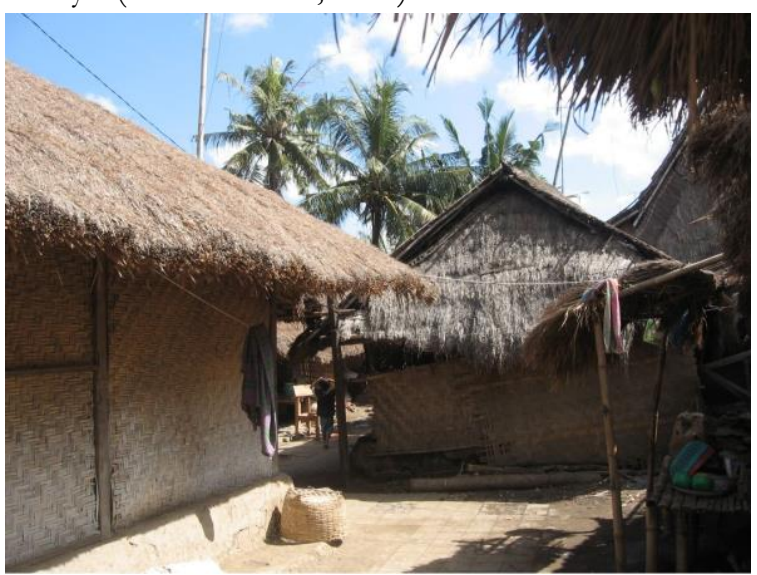

Gambar 3. Suasana permukiman dilihat dari dalam lingkungan.(Sumber: Pribadi 2008)

Sedang dalam konteks adjoining, permukiman ini merupakan gambaran bentuk dan tatanan arsitektur Sasak. Di dusun ini pada dasarnya dikenal empat jenis bangunan yang bisa dikategorikan sebagai arsitektur Sasak, yaitu: masjid, rumah, lumbung, dan sekepat. Di 
samping empat bentuk bangunan ini, ada banyak bangunan bergaya lain yang lebih 'modern' seperti rumah-rumah baru yang didirikan belakangan. Meskipun jumlah bangunan-bangunan non-tradisional ini menunjukkan semakin berkembang namun karena keberadaannya seperti telah diatur diletakkan di bagian belakang kompleks keberadaannya belum mampu menghapus karakter permukiman Sasak yang asli.

\section{LATAR BELAKANG PERUBAHAN LANSEKAP BUDAYA SADE}

Isu tentang keinginan perubahan bentuk dan pola hunian pada masyarakat Sasak sebenarnya sudah muncul cukup lama. Dalam sebuah laporan peneltian yang dilakukan oleh ITS pada tahun 1984 disebutkan bahwa hampir semua warga Sade pada saat itu menyatakan keinginan untuk membangun dan tinggal di rumah non tradisional. Alasan utama yang dikemukakan sebagian terbesar responden ialah bahwa rumah tradisional sulit untuk dikembangkan, misalnya untuk ditambah luasnya atau disekat ruang dalamnya untuk menampung kebutuhan baru (Penelitian ITS, 1984, V.49-V.50).

Apa yang diungkapkan di atas menjadi semakin nyata apabila langsung mengamati kondisi lapangannya. Bangunan-bangunan non-tradisional Sasak semakin merebak, seiring semakin terkisinya budaya agraris di kalangan mereka. Bahkan ada beberapa bangunan tradisional yang telah berubah total. Bahan bangunan modern semakin sering ditemukan. Rumah tidak lagi gelap di dalam karena penggunaan jendela kaca yang lebar yang tidak akan ditenukan pada rumah-rumah tradisional agraris. Demikian juga fungsi-fungsi baru dalam rumah mereka semakin banyak ditemukan. Saat ini ada tempat yang harus bisa dipakai untuk menyimpan motor, gaya hidup yang lebih individualistik telah menuntut adanya kamar-kamar pribadi, dan sebagainya.

Dari satu sisi perubahan ini dianggap sebagai indikator meningkatnya taraf ekonomi penghuninya. Namun apabila dibandingkan dengan kondisi di luar, yang terjadi di tempat ini ternyata belum mampu mengubah kesan Sade dari kemiskinan. Sade saat ini adalah Sade yang menuju perubahan tapi tidak naik status. Tampaknya, hal tersebut hanya mengindiksikan Sade yang mulai luruh dari semangat adat istiadat dan budaya tradisinya.

Kesan perubahan kultur juga terlihat dari semakin maraknya aktivitas produksi kerajinan kain songket yang kini mewarnai kehidupan sehari-hari kaum perempuan Sade. Sementara di sisi lain, semakin banyak pemuda Sade yang merantau bekerja untuk mendapatkan kehidupan yang lebih layak. Fenomena ini menunjukkan bahwa semakin mengecilnya daya dukung sumber daya pertanian meskipun mungkin saja ini juga sebagai akibat meningkatnya tuntutan gaya hidup masyarakatnya sendiri.

Singkatnya bisa dikatakan perubahan yang terjadi di tempat ini merupakan potret dari gejala proses pemarjinalan: pemarjinalan masyarakat dari kultur tradisinya, pemarjinalan masyarakat dari komoditasnya, 
dan pemarjinalan masyarakat dari kemerdekaan menentukan arah dirinya.

\section{UNSUR-UNSUR LANSEKAP BUDAYA DUSUN SADE YANG MENUJU PERUBAHAN}

\section{Tata Kehidupan}

Bagian perubahan ini yang paling menonjol adalah semakin maraknya kegiatan membuat kain songket oleh perempuan Sade yang cenderung lebih dominan dibanding kegiatan agrarisnya. Kesan adanya pergeseran ini akan terasa ketika masuk ke dalam kompleks. Hampir di setiap rumah pada siang hari ditemukan kegiatan menyongket dan pajangan produk di dekatnya. Bagi penduduk setempat, sepertinya menenun bukan lagi kegiatan pengisi waktu di sela kerja pertaniannya tapi telah menjadi profesi pokok. Seiring dengan perkembangan aktivitas wisata di dalamnya, songket telah menjadi bagian genius loci sekaligus komoditas penting penyangga ekonomi keluarga. Para perempuan bukan hanya bekerja dalam konteks berproduksi, tetapi juga beratraksi sekaligus menjajakan produknya. Tampaknya keseharian perempuan Sade akan bergeser dari menumbuk padi beralih ke menyongket dan dari menjemur padi beralih ke memajang dagangan.

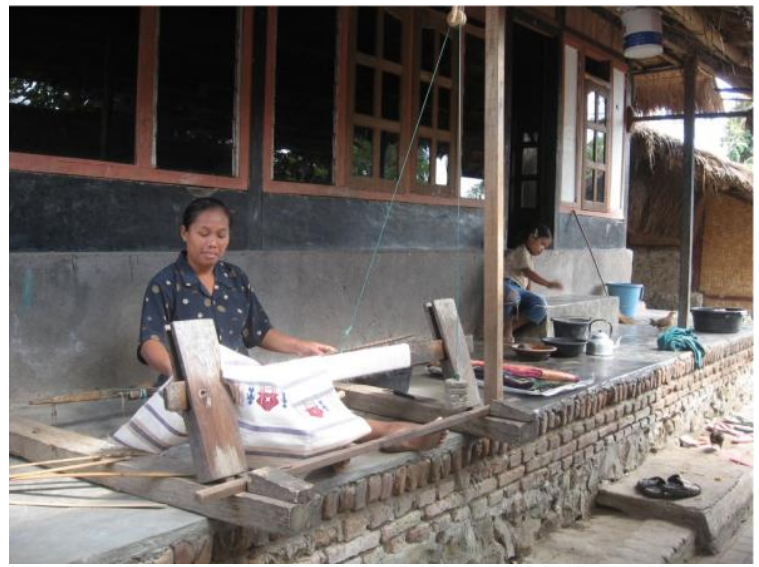

Gambar 4. Menyongket, kebanyakan dikerjakan di beranda rumah. (Sumber: Pribadi, 2008)

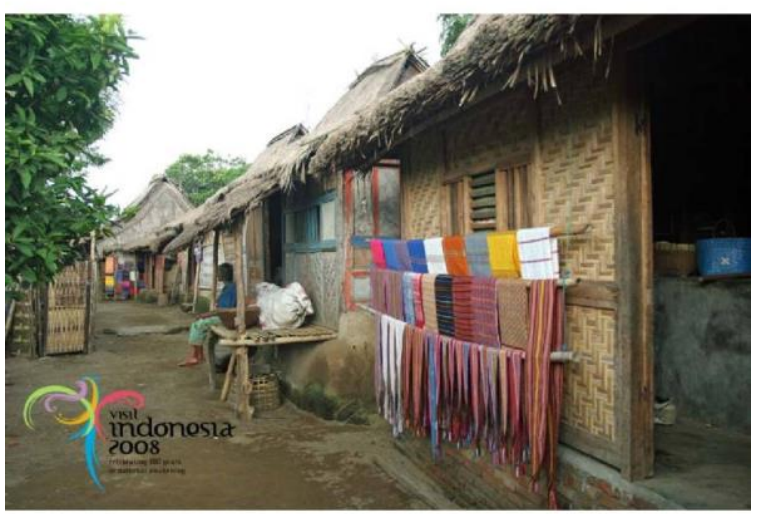

Gambar 5. Deretan pajangan kain songket di depan rumah penduduk. (Sumber: Setiadi Darmawan) 


\section{Tata Lingkungan}

Secara umum perubahan tata lingkungan permukiman ini belum begitu banyak terjadi. Tetapi karena terdapat pengembangan ruang di bagian muka yang utamanya untuk memenuhi wadah aktivitas pariwisata, karakteristik lingkungan seolah telah berubah total apabila hanya dilihat dari bagian depan kompleks ini.

Fungsi baru yang ikut mewarnai lansekap ini adalah tempat parkir pengunjung dengan jajaran kios cenderamatanya dan pelataran penerima baru. Tempat parkir dan kios cenderamata berada di bagian kanan pintu masuk dan keberadaannya secara visual terkesan terpisah dari tata lingkungan permukimannya. Walaupun secara fisik fungsi ini tidak terlalu mengubah pola tata lingkungan yang ada, kehadirannya telah memperkuat karakter Sade sebagai tempat wisata.

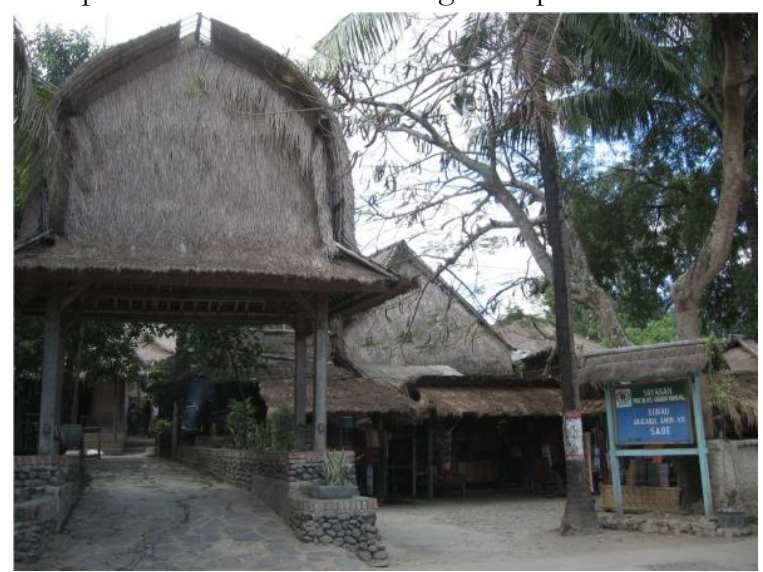

Gambar 6. Pintu gerbang utama dengan pelataran parkir di sisi kirinya. (Sumber: Pribadi, 2008)
Pelataran penerima yang baru berada di bagian kiri pintu masuk, didesain secara profesional, berupa arena berbentuk lingkaran dengan tribune di sekelilingnya. Dimensi ruang ini tidak terlalu besar, tetapi karena berada di dalam area permukiman fasilitas ini justru telah mengubah pola tata lingkungannya. Paling tidak, secara visual memperlemah fungsi gerbang utama berikut pelataran penerimanya yang sebelumnya sudah ada.

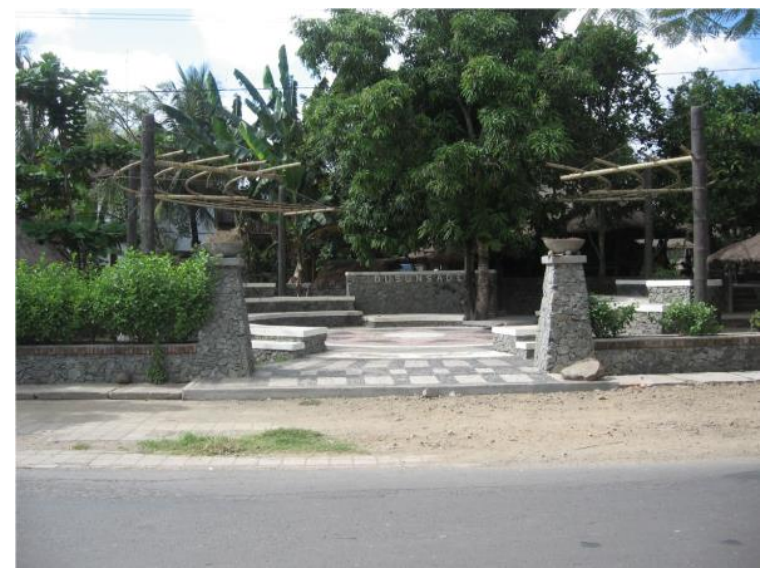

Gambar 7. Pelataran Penerima yang baru (Sumber: Pribadi, 2008)

\section{Tata Hijau}




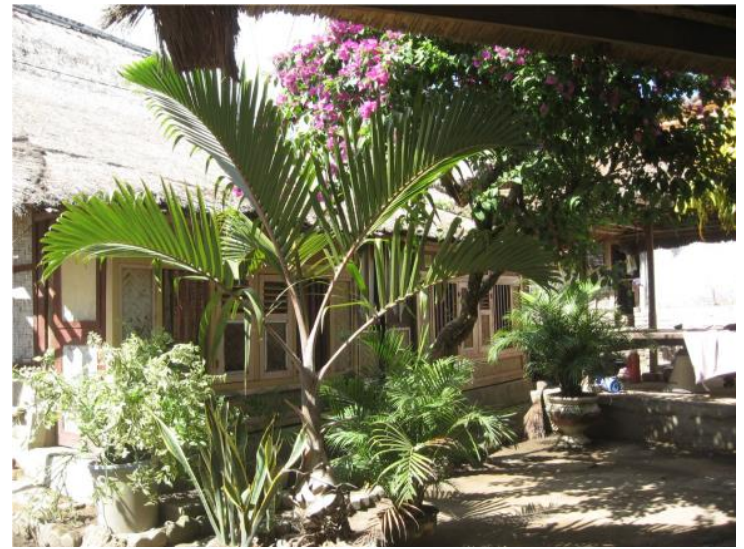

Gambar 8. Taman di salah satu rumah penduduk Sade. (Sumber: Pribadi, 2008)

Seperti halnya di permukiman tradisional pedesaan Jawa, konsep tata hijau tradisional Sade lebih ditekankan untuk tujuan-tujuan produktif. Namun saat ini Sade mulai mengenal vegetasi dalam konteks sebagai tanaman hias. Beberapa rumah ditemukan mulai menanam tanaman hias dalam pot dan tanaman yang dipilih bukan lagi sekedar tanaman yang mempunyai nilai produktif.

\section{Bentuk Bangunan}

Bentuk bangunan merupakan salah satu aspek yang paling menetukan perubahan karakter visual lansekap budaya Sade. Di lokasi ini semakin marak rumahrumah baru gaya modern yang tidak berbeda dengan rumah-rumah di luar lingkungan budaya ini. Dominasi rumah gaya modern ini memang masih berada di bagian belakang permukiman yang merupakan lokasi pengembangan. Tetapi tampaknya pengaruh tersebut akan cenderung semakin merembet ke depan masuk ranah kawasan tradisionalnya.

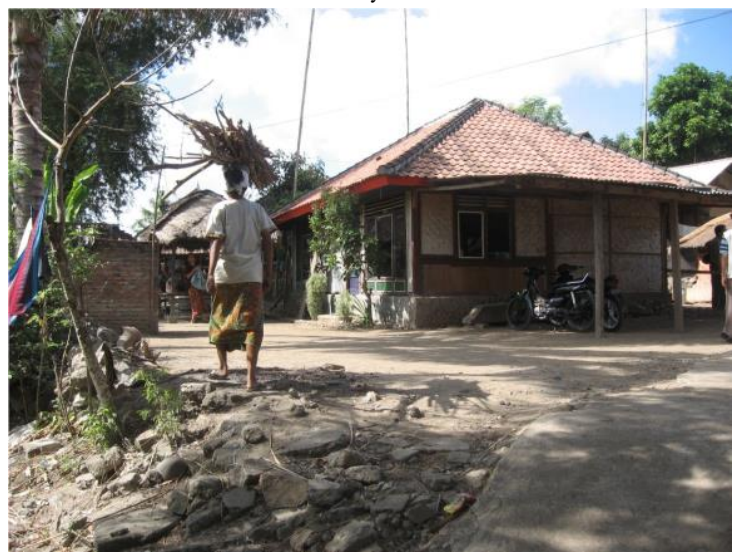

Gambar 9. Bangunan baru yang tidak mengikuti pakem tradisionalnya. (Sumber: Pribadi, 2008)

\section{Penggunaan Material}

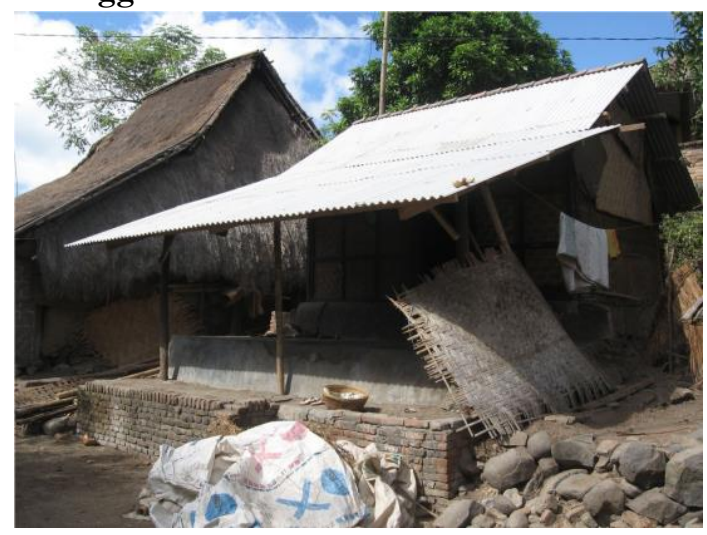

Gambar 10. Contoh kasus penggantian bahan penutup atap ke material asbes gelombang. (Sumber: Pribadi, 2008) 
Pemakaian material bangunan baru adakah aspek lain yang juga memiliki potensi berperan besar dalam mengubah karakter lansekap budaya Sade. Selama ini material yang bisa diidentikkan dengan permukiman Sade adalah pentup atap alang-alang, dinding bambu, kayu dan batu kali. Namun belakangan setelah genting, mulai ditemukan penggunaan material penutup atap lain seperti seng dan asbes gelombang. Untuk memperkeras halaman mulai banyak digunakan paving stone, sementara lantai rumah menggunakan keramik.

\section{KONSEP PELESTARIAN LANSEKAP BUDAYA YANG MAMPU MENGANTISIPASI PERKEMBANGAN}

\section{Pengertian Pelestarian Lansekap Budaya}

Pelestarian lansekap budaya dapat didefinisikan sebagai usaha manusia untuk memproteksi atau melindungi peninggalan atau produk budaya atau sisa-sisa budaya dan sejarah terdahulu yang bernilai dari berbagai perubahan yang negatif atau yang merusak keberadaannya atau nilai yang dimilikinya (Tisler, 1979). Pelestarian suatu benda atau suatu kawasan yang bernilai budaya, pada hakekatnya, bukan untuk melestarikannya tetapi utamanya untuk menjadi alat dalam mengolah transformasi dan revitalisasi kawasan tersebut (Qodarian,2001).

\section{Prinsip-prinsip dalam Pelestarian Lansekap Budaya Sade}

Berdasarkan temuan lapangan terdapat tiga aspek yang bisa digunakan sebagai dasar pengembangan proinsipprinsip pelestarian lansekap budaya Sade, yakni: a. Aspek potensi, meliputi: nilai sejarah kawasan sebagai salah satu tempat yang asal-usul suku Sasak.; kualitas lingkungan yang masih kuat karakternya sebagai pe5rmukiman tradisional sasak; dan lokasinya yang berada di tepi jalan menuju Pantai Kuta.

b. Aspek perubahan yang tidak bisa dihindarkan antara lain: pergeseran kultur masyarakat yang tidak lagi mengandalkan sektor pertanian; peningkatan aktivitas pariwisata yang cenderung membawa nilainilai baru; tuntutan perubahan tatanan rumah dan permukiman sebagai akibat perubahan budaya berhuni masyarakat; dan peningkatan aktivitas ekonomi khususnya pada sektor kerajinan.

c. Aspek perubahan yang harus dibatasi antara lain, perubahan karakteristik landscape visual sebagai akibat pmbangunan yang tidak memperhatikan karakter yang sudah ada; dan komersialisasi di segala sektor.

Berangkat dari aspek-aspek ini pelestarian lansekap budaya Sade hendaknya mendasarkan pada prinsipprinsip sebagai berikut:

a. Fokus utama penataan lansekap visual adalah mempertahankan karakter vernakular permukiman Sade yang natural, eksotis, dengan bentukanbentukan yang selama ini sudah dipahami sebagai bentukan arsitektur Sade.

b. Tetap menjaga spirit agrarisnya karena ini sudah menjadi bagian tak terpisahkan dengan lansekap budaya Sade. 
c. Mengakomodir dan mendorong tumbuhnya kegiatan-kegiatan kerajinan tenun sebagai upaya meningkatkan kemampuan ekonomi penduduk sekaligus daya tarik pariwisata di daerah ini.

d. Pelestarian lansekap budaya ini hendaknya sekaligus mampu meningkatkan kualitas lingkungan dan kualitas hidup masyarakat penghuninya.

e. Setiap upaya kerja pelestarian yang akan dilaksanakan, harus selalu memperhatikan preferensi penduduknya dan melibatkan peran serta masyarakat.

\section{Langkah-langkah Pelestarian}

Dengan mempertimbangkan bahwa warisan budaya yang akan dikelola berbentuk suatu tatanan yang terdiri dari berbagai sumberdaya budaya dan alam lokal, baik yang berbentuk fisik maupun non-fisik, maka upaya pelestarian hendaknya mempertim-bangkan berbagai hal yang bersifat holistik atau menyeluruh.

Proses pelestarian diawali dengan penggalian data dan informasi yang meliputi: aspek sejarah, budaya setempat, aspirasi masyarakat, aspek legal, dan karakter visualnya. Pada tahap analisa data, data dan informasi ini diolah untuk merumuskan potensi-potensi setempat, landasan legal yang diperlukan, sistem pengelolaan kawasan nantinya, dan kondisi fisik lansekap yang akan diolah. Out put dari proses analisis merupakan jabaran deskriptif dan visual yang nantinya akan dikembangkan sebagai konsep-konsep perencanaan, meliputi: deskripsi tatanan lansekap budaya, usulan sistem pengelolaan pelestarian, usulan alternatif pengembangan dan usulan konsep perencanaan. Secara skematis langkah-langkah bisa dilihat pada gambar berikut:

Skema 1. Skenario Proses Pelestarian Lansekap Budaya

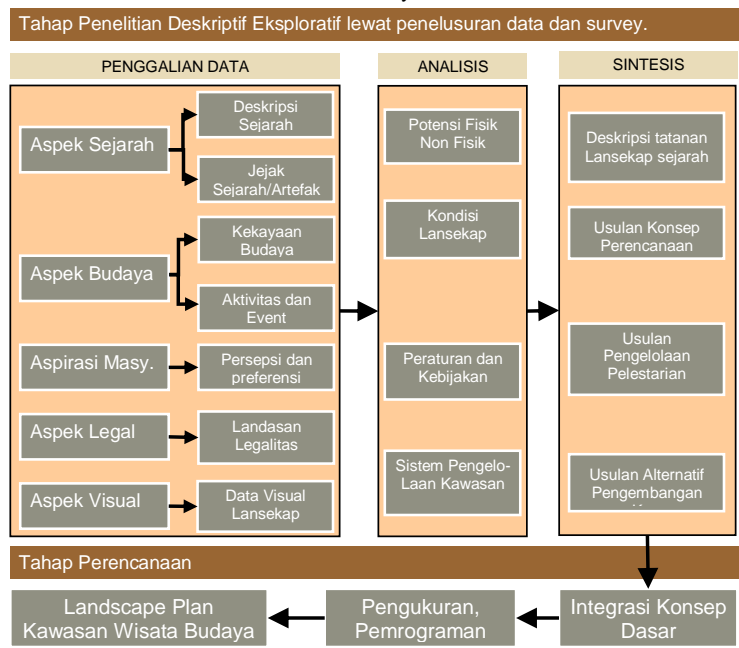

\section{KESIMPULAN DAN SARAN}

Dengan kacamata tertentu fenomena 'salah arah' perkembangan Dusun Sade bisa dipandang sebagai akibat adanya kooptasi satu ruang oleh ruang lain, yakni: yang agraris tradisional oleh yang kapitalis, sementara penghuninya belum siap. Tempat hidup yang tadinya bersifat eksklusif bagi warganya saat ini telah berkembang menjadi komoditas yang terbuka. Mungkin ada kesadaran akan terjadinya perubahan tersebut, tetapi karena tidak cukup memiliki bekal 
pengetahuan, kesempatan akses dan modal ekonomi yang bisa dipakai untuk ikut menentukan arah permainan, yang terjadi kemudian adalah sekedar mengikuti arus.

Lebih tepatnya mereka berubah karena dipaksa berubah. Mungkin ada kesadaran bahwa komoditas yang bisa dipakai sebagai modal eksis ke ruang kapitalis tersebut adalah apa yang selama ini ingin ditinggalkannya, bukan hanya segi fisiknya tetapi mencakup seluruh tradisi kehidupan yang bagi orang lain dipandang eksotis. Hanya karena adanya keterbatasan tersebut, tidak ada kemampuan bagi mereka untuk menentukan perubahan yang mampu mengkonservasi sekaligus mengembangkan potensi lingkungannya.

Tak dapat disangkal lagi sektor pariwisata mulai memainkan perannya sebagai motor ekonomi Dusun Sade. Hanya saja potensi ini tidak akan mampu mendorong peningkatan taraf hidup warga Sade secara significant selama mereka sendiri tidak mampu berperan lebih besar dalam menentukan arah pengembangan wilayahnya sendiri.

Untuk ini peran pemerintah sangat menentukan. Setiap kebijakan yang akan diambil, seharusnya selalu melibatkan masyarakat setempat atau paling tidak mengakomodasi aspirasi mereka. Pemerintah tidak cukup sekedar penyusun regulasinya saja. Ada tanggung jawab untuk terlibat aktif memberdayakan masyarakatnya sampai mencapai kemampuan untuk ikut menentukan arah kebijakan pengembangan Sade yang berkelanjutan.

\section{REFERENSI}

Funo, Shuji (1995). Cakeranegara, A Unique Hindu City in Lombok (Indonesia) The Grid in the Tradition of Asian City Planning. Surabaya: Makalah yang disampaikan dalam Seminar Arsitektur Nusantara, Keajekan dan Perubahan, World Trade Centre.

Handinoto (2000). Sistem Jalan di Cakranegara dan Purbolinggo, Sebuah Perbandingan. Jurnal Dimensi. Surabaya: Petra Press.

Sanoff H. (1991). Visual Research Method in Design. New York: Van Nostrand Reinhold.

Suardana, I.N.G. (2005). Arsitektur Bertutur. Denpasar: Yayasan Pustaka Bali.

Shuhana Shamsuddin \& Ahmad Bashri Sulaiman (2002). Developing A Guideline for Designing Urban Intervention in Places of Historical and Cultural Significance in Malaysia. Unpublished Research Report. Skudai, Johor Bahru: Jabatan Seni Bina, Fakulti Alam Bina. Universiti Teknologi Malaysia.

Spreiregen Paul D. (1965). Urban Design. The Architecture of Town and Cities. New York: McGraw-Hill.

Worskett (1969). The Character of Towns. London: Architectural Press. 